\title{
心理学における シチズン・サイエンスの可能性
} 高瀨堅吉

\section{はじめに \\ 一なぜ心理学にシチズン・サイエンスが 必要なのか}

2015年の8月にScience 誌で驚くべき結果が報 告された。過去の心理学の研究について再現実 験を行ったところ、その再現性が $40 \%$ にも満た ないというのだ。これは心理学界に衝撃を与え、 その事実は一般のマスコミにおいても報道され て社会に大きな波紋が広がった。心理学という 学問への社会からの信頼が摇らいだ瞬間だった。 同誌の報告によれば、心理学者 270 名が、三つ の高ランクの心理学の学術雑誌に掲載された研 究100件について組織的に再現実験を行ったと ころ、元の研究で統計的な有意差 $(\mathrm{p}$ 值が 0.05 以下）が認められた実験結果は、再現実験では $36 \%$ 程度しか統計的に有意である結果が得られ なかったというのだ。

この“心理学における再現性の危機”は、心 理学界が総力を挙げて解決すべき喫緊の課題と なった。解決方法の一つとして考えられるのは、 個々の先行研究について元の研究よりも大きな サンプルサイズで再現実験を行い、得られる結 果の精度を高めて知見を再確認することだ。こ の作業を通じて適切な知見のみを蓄積していく ことにより、心理学を“頑強な学問”に変えるこ とができる。しかし、アカデミア、とりわけ“実
験を研究手法の主軸と位置づける研究者コミュ ニティ”では、そもそも再現実験の結果をまと めた研究は業績として評価されづらい。そのた め、心理学における再現性の危機を解決する方 法は、それがわかっていても推進することが難 しいというジレンマに陥る。また、各研究者が 先んじて新しい知見を世に発表することが求め られる昨今の競争的環境下では、研究者間連携、 研究グループ間連携のもとにデー夕を共有して ビッグデー夕を生み出すことも困難であるため、 必然的に一つの研究で扱えるサンプルサイズに 限界が設けられてしまう。そのため、先述の“元 の研究よりも大きなサンプルサイズで行う再現 実験”も実施が困難となる。これらの理由から、 解決可能であるはずの“心理学における再現性 の危機”は、解決困難な問題として顕在化し、 同時に、再現性の保証という本来あるべきサイ エンスの姿を歪めてしまう体質を、現在の研究 者コミュニティが内包することを明らかにした。

心理学界は、この問題にただ手をこまねいて いたわけではない。Association for Psychological Science（APS）は、機関誌である「Perspectives on Psychological Science」の2012年11月号で 実験結果の再現可能性に関する特集を組み、こ の問題の重大性を広く世界的に周知した。そし てAPSは実際に行動を起こし、同誌に新たな論 文カテゴリー「Registered Replication Reports」 
を新設して、所定の手続きに則って行われた追 試を論文として積極的に掲載する方針を明らか にした。このような施策を心理学界は打ち出し、 再現実験の結果を論文として発表可能にする制 度を設けた。しかし、当然のことながら、その 制度を利用する研究者がいなければ問題は解決 しない。研究者コミュニティが内包する、1）再 現実験を業績として評価しない風土、2）競争的 環境下での研究者間の連携困難と、それによる スモールスケールな研究の横行という現状を改 善しなければ、心理学は今後も正しい知見を蓄 積することが難しい。心理学という学問の在り 方を真摰に問う心理学者の多くは、この現状に 焦りを感じはじめていた。

そんな折、私は文部科学省科学技術・学術政 策研究所（NISTEP）科学技術予測センターが 運営する「KIDSASHI（きざし)」というサイト で、「欧米における市民科学（シチズンサイエン ス）支援の動き」という記事を目にした。シチ ズン・サイエンスとは、一般の人々によって行 われる科学であり、職業的な科学者や研究機関 と協調して行われることの多い活動を指す（シ チズン・サイエンスの詳細については、本特集 に掲載されている林の記事を参照)。私は、シチ ズン・サイエンスがどのようなものかを学ぶに つれて、シチズン・サイエンスに参画する市民 科学者、すなわち、シチズン・サイエンティス トであれば、研究者コミュニティの体質により 生ずる問題を上手く乗り越えられるのではない かと考えはじめた。

そもそも、科学という営みのこれまでを考え

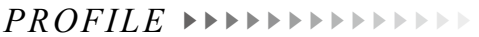

高瀨堅吉（たかせ けんきち）

ロ日本学術会議若手アカデミー幹事・イノイ ションに向けた社会連携分科会副委員長

-日本学術会議連携会員

-自治医科大学大学院医学研究科教授

專門 発達生物心理学・臨床発達心理学

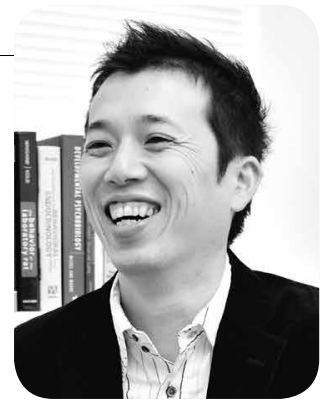

れば、再現実験、研究者間連携は推奨されるべ き行為である。しかし、現在の研究者コミュニ ティでは、それらの行為よりも、新しい発見、 新しい概念を他の研究者、研究グループよりも 先んじて報告することが善しとされる。この原 因は、アカデミックポストをめぐる過剩な競争 の横行にあり、これが研究者間連携、研究グルー プ間連携をも障害し、共創原理を基調とした データの共有、それによる再現性の検証を難し くしている。現在の研究者コミュニティの狭間 に、本来あるべきサイエンスの姿が取り残され てしまい、競争原理のもとで動く職業研究者で は手のつけられない課題が積み残されてきてい るのだ。心理学の再現性の危機も、それら積み 残された課題の一つだと私は考えている。そし て、その課題群にアプローチする公共事業こそ が、今の学術には必要なのだと私は考える。シ チズン・サイエンスは、その公共事業を行う仕 組みの一つだ。

先述の「KIDSASHI（きざし)」に掲載された シチズン・サイエンスの記事を目にした頃、私 は日本心理学会の中で“認定心理士”と呼ばれる 市民の心理学者（シチズン・サイコロジスト） の活動を促進する活動に関わっていた。後で詳 述するが、認定心理士は心理学の専門家として 仕事をするために必要な最小限の標準的基礎学 力と技能を修得していることを日本心理学会が 認定した方たちであり、有資格者の多くは市民 
である。現在では約 55,000 人の認定心理士がお

り、社会で活躍をしている。

心理学の再現性の危機、シチズン・サイエンス、 認定心理士、これら三つのキーワードが当時の 私の中で交差したときに、次のようなアイデア が生まれた。それは、“心理学における大規模再 現実験を認定心理士のネットワークを通じて精 度高く行い、良質のビッグデータを創出して再 現性の危機に挑戦する”というものだった。

\section{認定心理士}

\section{ーシチズン・サイコロジストは} 如何に誕生するのか

認定心理士は、心理学の専門家として仕事を するために必要な最小限の標準的基礎学力と技 能を修得していることを日本心理学会が認定し た方たちである。その審査は、日本心理学会の 資格認定委員会が行い、同委員会は、申請者が 提出した「心理学関係科目修得単位表」に記載 された内容を中心とする書類審査によって認定 の可否を決定する。この「心理学関係科目修得 単位表」は、申請者が学会所定の様式で記載し たものだ。の単位表の「基礎科目」・「選択科 目」に割り付けられている「科目名」（開講され た講義・演習などの正式題目)、担当者氏名・職 名、単位数、学年、期間、および、その科目の 内容がその認定領域に対して妥当なものか、「領 域」ごとに規定されている必要単位数を満たし ているか、単位数が基礎科目・選択科目の各「小 計」および「総計」でそれぞれ規定の単位数を
満たしているかが、資格認定委員会では厳しく 検討される。

資格認定委員会では、個人から提出された「心 理学関係科目修得単位表」の記載内容が一定の 基準に達していると判定した場合は申請者を「認 定心理士」として認定することを決定し、その 旨を申請者に通知する。通知を受けた申請者か らの認定料の払込の手続きなどが完了した時点 で、日本心理学会事務局に整備されている「日 本心理学会認定心理士名簿」に認定資格取得者 として氏名を登録し、事務局から「認定心理士 認定証」と、認定当時の写真を貼付した「認定 心理士証（ID カード）」が送付される。資格認 定委員会で所定の基準に達していないと判定さ れた場合も、申請者にはその旨を通知する。ま た、審査段階で記載事項に不備・不明確な部分 があったり記載内容に疑問があったりして合否 がすぐには判定できないことがあるような場合 には、事務局を通して申請者本人に直接問い合 わせたり書類の再提出を求めたりする。内容に よっては、証明した教員、または機関に問い合 わせたりすることもある。これらの場合は審査 の判定は「保留」になり、回答を待って「再審査」 ということになる。

資格認定委員会は原則的には年およそ6回開 催されるので、通常は申請書類提出後 $2 \sim 3$ か 月以内に結論が出るが、再審査になると最終審 査結果が得られるまでにさらに 2 〜か月かか ることになる。なお、認定業務の現況は、資格 認定委員会から日本心理学会理事長、日本心理 学会理事会、および総会に定期的に報告される 
ことになっている。このような精緻かつ厳正な 手続きを経て、認定心理士は誕生する。

先述のように、認定心理士とは「心理学の 専門家として仕事をするために必要な、最小限 の標準的基礎学力と技能を修得していると日本 心理学会が認定した人」である。つまり、この 資格を得たからといって何らかの職業に就ける ことや職務内容が保証されることは基本的にな い。それにもかかわらず、1990年に認定心理士 の認定制度が発足して以降、取得者数は急増し、 2005年以降は毎年 3,000 名を超える認定心理士 が誕生している。2016年度末時点では総取得者 数が53,000名を超え、現在もその数は増え続け ている。認定心理士 25 周年記念事業の一環とし て、認定心理士有資格者を対象にアンケート調 査を行ったところ、多くの認定心理士が、“心理 学を学んだ証”、“自分自身のアイデンティティ” としてこの資格を保有していることがわかった。 また、認定心理士取得者の仕事（社会生活）に ついても調査を行い、有資格者の $79.9 \%$ が就労 しており、会社員、自営業、公務員、パート・ アルバイト、学生、主婦・主夫など、様々な地 域や職域で活動している市民の方たちが、この 資格を取得していることもわかった。つまり、 認定心理士の多くは、市民であり、彼らは市民 の心理学者、すなわち“シチズン・サイコロジ スト”だったのだ。

\section{認定心理士の活動の現状と展望 ーシチズン・サイエンスを越えて}

実は1990年に認定心理士の認定制度が発足し て以降、学会としての認定心理士へのサービス はあまり活発でなかった。学会として認定して おきながらこの状況は良くないとの意向が 2014 年から2015年にかけて提言された。また、先述 の認定心理士を対象としたアンケートの調査報 告書によれば、認定心理士で構成する組織への 興味を有する方が $71.8 \%$ との調査結果もあった。 これを受けて、日本心理学会は2016年4月、日 本心理学会の中に「認定心理士の会」を発足さ せた。この会の目的は「資格取得者の相互の連 携を密にし、認定心理士の資質と技能の向上を はかるとともに、人々の心の健康と福祉の増進 に寄与すること」と規定されている。この会の 立ち上げを進めてきた私を含む幹事一同は、会 則に示されるこの目的の冒頭部分が現状にて特 に重要と考えて、認定心理士が交流したり繋がっ たりできる機会を作れるようにと思いながら活 動した。また、近い将来、様々な地域や職域に いる方々が、会から提供される何かを待つので はなく、主体的に学びや活動を行う際に会を利 用する展開が理想だと考えた。発足当時のこの 精神は現在も変わっていない。

認定心理士の会発足後、シンポジゥムやワー クショップの開催、交流会・懇親会、ニュー ズレター（メール配信およびWebでの閲覧）、 Webでの交流などの活動が進み、より身近な ネットワーク作りを目指す地方支部会（北海道 
支部会、東北支部会、関東支部会、北陸支部会、 東海支部会、近畿支部会、中国・四国支部会、 九州・沖縄支部会）も発足した。さらに2017年 の日本心理学会大会時に「認定心理士の会運営 委員会」が日本心理学会の常置委員会として設 置されることが決定し、私が委員長を帱命する こととなった。

認定心理士の会運営委員会では、認定心理士 にとっての資格の意義を満たしたり、今以上に 「この資格を取得して良かった」と感じてもらっ たりするような事柄を第一に考え続けなくては いけないと思っている。そこで、これまでの活 動に加えて、1）シチズン・サイコロジスト奨励 賞の設立、2）認定心理士が日本心理学会の大会 で自身の活動を発表する社会連携セクションの 設置、3）認定心理士が研究に参画するシチズン・ サイエンスプロジェクトを行うこととした。シ チズン・サイコロジスト奨励賞は、人々の心の 健康と福祉の増進に寄与する認定心理士を顕彰 することにより、社会への心理学の普及をより 一層促進させることを目的として設立した。認 定心理士の貢献が社会に広く知られることが日 常化したとき、日本における心理学の真の社会 連携が達成されると考えている。受賞対象は、 社会において優れた活動を行い、人々の心の健 康と福祉の増進に寄与した認定心理士とし、高 等教育機関、研究機関に所属しないことを条件 とした。このようなシチズン・サイエンティス トを対象とした賞の設立は、学協会ではあまり 例がないことだと思う。また、認定心理士が日 本心理学会の大会で自身の活動を発表する社会
連携セクションの設置については、来年度の実 施を目指して事業を進めている。日本心理学会 では 2017 年度の大会から学部学生の積極参加を 奨励している。大学と社会の接続強化が求めら れる時代背景を勘案し、社会で心理学の知見が どのように活かされているのかを認定心理士に 発表のなかで示してもらい、学部で学んだ心理 学の知識が研究者になるためだけのものではな く、社会で活きるものであることを学部学生に 理解してもらいたいとの思いから社会連携セク ションの設置を考案した。最後に、シチズン・ サイエンスプロジェクトの実施については、先 述のとおりである。研究に参画したい認定心理 士が潜在的に多いことを勘案し、“心理学の再現 性の危機”を始めとする現在の研究者コミュニ ティの狭間に取り残されてしまったサイエンス の本来あるべき姿を、シチズン・サイコロジス トである認定心理士が取り戻す戦いがこれから 始まるのだ。

今年、7月 28 日にシチズン・サイエンスに関 するシンポジウムを、私は主導して企画した。 そのシンポジウムのポスターも私が作製したの だが、その背景をウジェーヌ・ドラクロワによっ て描かれた「民衆を導く自由の女神」にした。 これは 1830 年に起きたフランス 7 月革命（7/27 〜 7/29）を主題としている。“市民とともに本 来のサイエンスの姿を取り戻す”。これは改革で はなく革命だ。 
参考文献・URL

Open Science Collaboration. PSYCHOLOGY. Estimating the reproducibility of psychological science. Science. 2015;349(6251):aac4716. doi: 10.1126/science.aac4716.

Open Science Collaboration. An Open, Large-Scale, Collaborative Effort to Estimate the Reproducibility of Psychological Science. Perspect Psychol Sci. 2012;7(6):657-60. doi: 10.1177/1745691612462588.

Perspectives on Psychological Science "Registered Replication Reports” https://www.psychologicalscience. org/publications/replication

KIDSASHI（きざし）“欧米における市民科学（シチズンサイ エンス）支援の動き” https://stfc.nistep.go.jp/horizon2030/ index.php/ja/weekly-weakly-signals/228

認定心理士アンケート調査報告書一日本心理学会 https:// psych.or.jp/wp-content/uploads/2017/09/201502-03_ result.pdf

シチズン・サイコロジスト奨励賞一日本心理学会 https:// psych.or.jp/prize/citizen/

公開シンポジウム「若手アカデミーが考えるシチズンサイエ ンスに基づいた学術横断的社会連携」http://www.scj.go.jp/ ja/event/pdf2/261-s-0728.pdf 